\title{
MULTISTATE PUBLICATION IN RADIO AND TELEVISION
}

\author{
Harry P. Warner*
}

I

The Single Publication Rule

In 1955, California, a focal state for radio and television activities, enacted the Uniform Single Publication Act, ${ }^{1}$ promulgated in 1952 by the National Conference of Commissioners on Uniform State Laws and the American Bar Association. ${ }^{2}$ The heart of this legislation is formed by the following two sections:

Sec. 3425.3. No person shall have more than one cause of action for damages for libel or slander or invasion of privacy or any other tort founded upon any single publication or exhibition or utterance, such as one issue of a newspaper or book or magazine or any one presentation to an audience or any one broadcast over radio or television or any one exhibition of a motion picture. Recovery in any action shall include all damages for any such tort suffered by the plaintiff in all jurisdictions.

Sec. 3425.4. A judgment in any jurisdiction for or against the plaintiff upon the substantive merits of any action for damages founded upon a single publication or exhibition or utterance as described in section 3425.3 shall bar any other action for damages by the same plaintiff against the same defendant founded upon the same publication or exhibition or utterance.

The purpose of this legislation was to codify into statute the rule recently adopted by several courts ${ }^{3}$ that tortious interference by a single issue of a newspaper or

- LL.B. 1937, University of Michigan. Member of the California and District of Columbia bars. Resident Counsel, Paramount Television Productions, Inc., and Paramount Sunset Corporation, Hollywood, Cal. Author, Radio and Television Law (1949), and Radio and Television Rigits (1953). The opinions and conclusions expressed herein are those of the author and do not necessarily reflect the views of any other person, firm, or corporation.

${ }^{1}$ CaI. Crv. Code 3425.1 et seq. (Supp. 1955). In addition to California, the following states have adopted the Uniform Single Publication Act: Arizona, Aruz. Rev. Stat. ANN. $\$ \S$ 27-200r-05 (Supp. 1954); Idaho, IDAHO CoDE \$\$ 6-702-05 (Supp. I955); North Dakota, N. D. Rev. Code \$\$ 14-0210-I4 (Supp. 1953); Pennsylvania, PA. Stat. ANN. tit. 12, \$ 2090.I-5 (Supp. I954).

${ }^{2}$ National Conference of Commissioners on Uniform State Laws, Handbook (1952).

${ }^{3}$ See, e.g., Hartmann v. Time, Inc., 166 F.2d 127 (3d Cir.), cert. denied, 334 U.S. 838 (1948); Kilian v. Stackpole Sons, 98 F. Supp. 500 (M.D. Pa. I95I); Stephenson v. Triangle Publications, Inc., I04 F. Supp. 215 (S.D. Tex. 1952); Gregoire v. G. P. Putnam's Sons, 298 N.Y. II9, 81 N.E.2d 45 (1948); Ettore v. Philco Television Broadcasting Corp., 229 F.2d $48 \mathrm{r}$ (3d Cir.), cert. denied, $35 \mathrm{I}$ U.S. 926 (1956); Bernstein v. National Broadcasting Co., I29 F. Supp. 8I7 (D.D.C. 1955), $a f^{\prime} d, 232$ F.2d 369 (D.C. Cir.), cert. denied, 352 U.S. 945 (1956); Fouts v. Fawcett Publications, Inc., 116 F. Supp. 535 (D. Conn. I953); Hazlitt v. Fawcett Publications, Inc., II6 F. Supp. 538 (D. Conn. 1953); Dale System, Inc., v. Time, Inc., I16 F. Supp. 527 (D. Conn. I953); Dale System, Inc., v. General Teleradio, Inc., I05 F. Supp. 745 (S.D.N.Y. 1952). There is a growing body of literature on the single publication rule: Prosser, Interstate Publication, 5I Mrch. L. Rev. 959 (1953); Leflar, The Single Publication Rule, 25 Rocky MT. L. Rev. 263 (1953); Leflar, Choice of Law: Current Trends, 6 VAND. L. Rev. 447 (1953); 
magazine or by a nationwide broadcast with a legally recognized right gives rise to a single cause of action, whether the interference be by a defamatory utterance, ${ }^{4}$ an invasion of privacy, ${ }^{5}$ the right of publicity, ${ }^{6}$ or unfair competition. ${ }^{7}$ Although thousands of widely-distributed copies or a nationwide audience of viewers-listeners may be involved, there is, in legal effect, but one integrated publication. The number of copies sold or the extent of the audience do not create separate causes of action; they go to the measure of damages and constitute competent proof as to the degree of the injury suffered. ${ }^{8}$

The foregoing statement is not intended as an all-inclusive definition of the "single publication rule." The latter is one of the most complex and baffling doctrines in our jurisprudence; it has been badly misunderstood and its meaning and scope remain uncertain. As has been pointed out, "the words 'single publication rule' became a catch-phrase exemplifying a type of reform vigorously favored by many who felt that the law of libel was made up largely of historical anachronisms unsuited to the practical needs of modern time. The phrase sounded good, regardless of what it might mean in detailed application."

The "single publication rule" is a very recent development in our jurisprudence; it is a twentieth-century doctrine premised on modern methods of mass communication to the public-the newspaper and national magazine crossing state lines, the motion picture exhibited in forty-eight states, and the nationwide radio-broadcast or telecast.

The antithesis of the "single publication" doctrine was the old common-law rule, as exemplified by Duke of Brunswick v. Harmer. ${ }^{10}$ In that case, it was held that each sale or delivery of a single copy of a newspaper or magazine was a distinct or

Remmers, Recent Legislative Trends in Defamation by Radio, 64 HARv. L. Rev. 727 (195I); Ludwig, "Peace of Mind" in 48 Pieces v. Uniform Right of Privacy, 32 MrN. L. REv. 734 (I948); Note, 60 Harv. L. Rev. 94I (1947); Note, 28 N.Y.U. L. Rev. 1006 (1953); Note, 48 Colum. L. Rev. 932 (1948); Cheatham and Reese, Choice of the Applicable Law, 52 Colum. L. Rev. 959 (I952); Morris, Proper Law of a Tort, 64 HARv. L. Rev. 88I (I95I).

'See, e.g., Dale System v. Time, Inc., supra note 3; Fouts v. Fawcett Publications, Inc. supra note 3; Dale System, Inc., v. General Teleradio, Inc., supra note 3.

${ }^{6}$ See, e.g., Bernstein v. National Broadcasting Co., 129 F. Supp. 817 (D.D.C. I955), $a f d^{\prime}, 232$ F.2d 369 (D.C. Cir.), cert. denied, 352 U.S. 945 (I956).

' Nimmer, The Right of Publicity, 99 Law \& Contemp. PROB. 203 (I954).

' Sec, e.g., Ettore v. Philco Television Broadcasting Corp., 229 F.2d $48 \mathrm{I}$ (3d Cir.) cert. denied, $35 \mathrm{I}$ U.S. 926 (1956).

${ }^{8}$ Mattox v. News Syndicate Co., r76 F.2d 897 (2d Cir. 1949).

${ }^{\circ}$ Leflar, The Single Publication Rule, 25 Rocky Mr. L. Rev. 263, 269 (r953). Palmisano v. News Syndicate Co., I30 F. Supp. I7, I9 n. I (S.D.N.Y. x955): 'The so-called 'single publication rule' which embodies the composite tort concept has been applied in greatly varying legal contexts each of which has policies and purposes which are at times inconsistent with the ends sought to be furthered in one of the other legal contexts. For instance, the supposedly all-purpose 'single publication rule' may be applied in these differing contexts; achieving joinder in one action of separate local libel claims; determining, for purposes of the forum's statute of limitations, when a claim for libel based on successive printings of a magazine or a book arose; determining the venue of a local libel claim as amongst the various subdivisions of a state; and, for choice-of-law purposes, determining the single state whose laws should apply to multi-state publication of a libel."

${ }_{14}^{10}$ Q.B. I85, II7 Eng. Rep. 75 (1849). 
separate publication of a libel therein contained. This rule is still followed by several jurisdictions. ${ }^{11}$ Thus, the application of the common-law rule means that when a defamatory utterance is published in a magazine with national circulation, the person defamed may have as many as 3,900,000 possible causes of actions for separate torts based on the publication to each individual reader. ${ }^{12}$

The genesis of the "single publication rule" can be attributed to the statute-oflimitations problems likewise presented by Duke of Brunswick v. Harmer. In that case, the action was based on a defamatory statement appearing in a newspaper published seventeen years before the action was brought. The defensive plea of the then-existing statute of limitations, which was six years, was overruled. The court held that the sale and delivery of the newspaper to plaintiff's agent seventeen years after the date of its issue was a new publication.

A century later, the New York Court of Appeals, confronted with substantially the same issue, applied a different statute of limitations to bar such a suit and, in so doing, evolved the "single publication rule." In Gregoire v. G. B. Putnam's Sons," a book, allegedly containing defamatory material, was originally distributed in 194r; it had gone through seven additional printings, the last of which was in I943. In the one-year period preceding the filing of the libel suit on July 2, 1946 , only sixty copies had been sold from stock. The New York statute of limitations for defamation is one year. The court of appeals, in barring the claim, held that the rule of Duke of Brunswick v. Harmer had its origin in an era which long antedated the modern process of mass publication and nationwide distribution of printed information. That rule also gave scant heed to the public policy which underlies statutes of limitation, long regarded as "statutes of repose designed to outlaw stale claims. ... Recognizing that radical changes have been brought about by modern methods of disseminating printed matter ... and desiring to avoid multiplicity of suits and to give effect to statutes of limitations ... the publication of a defamatory statement in a

${ }^{21}$ Restatement, TorTs $\S 578$, comment $b$ (1938): "Each time a libelous article is brought to the attention of a third person, a new publication has occurred, and each publication is a separate tort. Thus each time a libelous book or paper or magazine is sold, a new publication has taken place which, if the libel is false and unprivileged, will support a separate action for damages against seller. So, too, each time a libelous article is reprinted or redistributed, a new publication is made and a fresh tort committed." To the same effect: Hartmann v. American News Co., 69 F. Supp. 736 (W.D. Wis, 1947), aff'd, 17I F.2d 58I (7th Cir. 1948); Holden v. American News Co., 52 F. Supp. 24 (E.D. Wash. 1943); O'Reilly v. Curtis Publishing Co., 3I F. Supp. 364 (D. Mass. 1940). Compare Renfro Drug Co. v. Lawson, 138 Tex. 434, I6o S.W.2d 246 (1942), with Stephenson v. Triangle Publications, Inc., 104 F. Supp. 215 (S.D. Texas 1952). See, also, Martin L. Neweld, The Law of Slander and Linel in Civl and Criminal Cases $\$ \$$ 175, 192 (4th ed. 1924).

${ }^{12}$ National Conference of Commassioners on Uniform State Laws, Handoook 432-33 (1952); Leflar, The Single Publication Rule, 25 Rocky Mr. L. Rev. 263 (1953).

${ }^{13} 298$ N.Y. 119, 8I N.E.2d 45 (1948). The holding in the Gregoire case was foreshadowed in Wolfson v. Syracuse Newspapers, 254 App. Div. 211,4 N.Y.S.2d 640 (4th Dep't 1938), aff'd suithonte opinion, 279 N.Y. 716, 18 N.E.2d 676, rehearing denied, 280 N.Y. 572, 20 N.E.2d 21 (1939). To the same effect: Means v. Macfadden Publications, Inc., 25 F. Supp. 993 (S.D.N.Y. I939); Cannon v. Time, Inc., 39 F. Supp. 660 (S.D.N.Y. x939); Age-Herald Pub. Co. v. Huddleston, 207 Ala. 40, 92 So. 193 (I92I); Forman v. Mississippi Publishers Corp., 195 Miss. 90, 14 So.2d 344 (r943); McGlue v. Wcekly Publications, Inc., 63 F. Supp. 744 (D. Mass. I947); Winrod v. Time, Inc., 334 Ill. App. 59, 78 N.E.2d 708 (I948). 
single issue of a newspaper, or a single issue of a magazine, although such issues consist of thousands of copies widely distributed, is, in legal effect, one publication which gives rise to one cause of action and that the applicable statute of limitations runs from the date of that publication."14

The philosophic basis of the "single publication rule" is the danger of multiple lawsuits which could plague and harass publishers of national magazines and newspapers and national and regional networks and broadcasters. ${ }^{15}$ Similarly, the extension of statutes of limitations, because one copy of the original edition is distributed at a later date, might extend liability more or less indefinitely. ${ }^{\mathbf{1 6}}$

The significance of the "single publication rule" is that the entire edition of a newspaper or magazine constitutes a single publication, giving rise to one cause of action within the state. The mailing of late copies, ${ }^{17}$ or sales from stock, ${ }^{18}$ or reading defamatory material in defendants' files ${ }^{\mathbf{1 9}}$ is still part of the original publication. Whether the single publication would extend to a subsequent edition of a newspaper or a new edition of the same book is still an open question, though probably publication of the same defamatory article in a later edition of the newspapers would give rise to a new cause of action. ${ }^{20}$ The Gregoire case, which involved seven printings of the same book, suggests a different rule, but a careful reading of the opinion indicates that there were seven successive libels-the last of which became actionable in 1944, when distribution of the final printing was begun, and still more than two years before the plaintiff brought his action.

\section{II}

Interstate Publication and the Single Publication Rule

The foregoing discussion relates to the application of the "single publication rule" within one state. The problems became infinitely more complex in interstate publica-

14 298 N.Y. at 123, 126, 8r N.E.2d at 47.

${ }^{26}$ Prosser, supra note 3, at 969: "The 'chain libel suit' which can result is no figment of the imagination. Professor Hartman brought six suits against Life for calling him subversive and a fascist. The late Annie Oakley, currently famed in "Annie Get Your Gun," once was reported by the Associated Press to have been arrested as a drug addict, and proceeded to bring fifty different actions against as many newspapers, of which she won forty-eight, with damages ranging from $\$ 500.00$ to $\$ 27,500.00$. An Ohio congressman named Sweeny, who was accused in Pearson and Allen's syndicated column of being a spokesman for Father Coughlin and opposing the appointment of a foreign-born Jew to the federal bench, brought a number of actions which has been reported as anywhere from sixty-eight to three hundred, claiming a total of damages estimated at $\$ 7,500,000$, with at least fifteen reported opinions in the courts."

${ }^{10}$ See note 13 supra.

${ }^{17}$ McGlue v. Weekly Publications, Inc., 63 F. Supp. 744 (D. Mass. 1947); Winrod v. Time, Inc., 334 Ill. App. 59, 78 N.E.2d 708 (1948); Backus v. Look, Inc., 39 F. Supp. 662 (S.D.N.Y. 194I).

${ }^{10}$ Gregoire v. Putnam's Sons, 298 N.Y. rr9, 81 N.E.2d 45 (1948).

${ }^{10}$ Wolfson v. Syracuse Newspapers, Inc., 254 App. Div. 21 I (4th Dep't 1938), affd without opinion, 279 N.Y. 716, 18 N.E.2d 676, rehearing denied, 280 N.Y. 572, 20 N.E.2d 21 (r939).

${ }^{20}$ Backus v. Look, Inc., 39 F. Supp. 662 (S.D.N.Y. 194I); Means v. Macfadden Publications, Inc., 25 F. Supp. 993 (S.D.N.Y. 1939); Mack Miller Candle Co. v. Macmillan Co., 239 App. Div. 738, 269 N.Y. Supp. 33 (4th Dep't 1934), aff'd, 266 N.Y. 489, 195 N.E. I67 (1934); Sharpe v. Larson, 70 Minn. 209, 72 N.W. 96I ( 1897$)$. 
tions, as demonstrated by Hartmann v. Time, Inc. ${ }^{21}$ Hartmann brought an action in the Federal District Court of Pennsylvania to recover damages for an allegedly libelous article published by defendant in Life magazine, which was circulated throughout the forty-eight states and many foreign countries. ${ }^{22}$ Federal jurisdiction was based on diversity of citizenship, so that under the teachings of Erie R. Co.v. Tomp$k_{i n s,}{ }^{23}$ state law, including state rules of conflict of laws, was required to be applied. The trial court, finding that Pennsylvania adhered to the "single publication" rule, held that Hartmann's one and only cause of action accrued at the time of initial publication in Illinois and was barred by the Pennsylvania statute of limitations. On appeal, the Court of Appeals for the Third Circuit agreed that Pennsylvania would follow the "single publication rule." However, as a person's reputation is damaged wherever a statement libeling him is read, the court would also examine the law of each state where publication occurred. Since Illinois followed the "single publication" rule, and since the cause of action was barred by the one-year Pennsylvania statute of limitations, the Illinois publication of the accused magazine issue engrossed, as it were, the Pennsylvania publication. Since there was but one cause of action in both states, the Pennsylvania statute of limitations effectively barred the action in both, and in all jurisdictions having the "single publication rule." In those states which adhered to the multiple-publication theory, each publication could result in fresh causes of action, which would not necessarily be barred by the Pennsylvania statute of limitations. The court, therefore, partially vacated the judgment of the lower court and remanded with instructions to decide the case with reference to the laws of those multiple-publication states where the magazine had circulated.

The Hartmann case has far-reaching implications. In applying the "single publication rule" across state lines, it concluded that the facts constituted a single tort committed in the place of earliest publication and radiating into other states only in its damaging effects. In applying the multiple-publication theory in regard to those states not bound by the "single publication rule," the decision imposed an onerous task on the lower court. The latter would be required to wade through and digest the law of forty-eight states to determine the existence of a cause of action in defamation, privacy, publicity, or unfair competition. The same inquiry would be required for pleas of privilege or other matters of defense. The task before a trial judge in instructing the jury as to the law of libel or privacy of each jurisdiction, or the various peculiarities concerning damages, defies imagination. ${ }^{24}$

${ }^{21}$ I66 F.2d I27 (3d Cir. 1948), cert. denied, 334 U.S. 838 (1948).

${ }^{22} 64$ F. Supp. 671 (E.D. Pa. 1946).

28304 U.S. 64 (1939).

24 Mattox v. News Syndicate Co., I76 F.2d 897, 900 (2d Cir. 1949): "The difficulty is that in application it would prove unmanageable. ... It would certainly be an unworkable procedure to tell a jury that they should award damages, so far as they were suffered in State $X$, according to one measure, and, so far as they were suffered in State $\mathrm{Y}$, according to another."

Curley v. Curtis Publishing Co., 48 F. Supp. 29, 39 D.3 (D. Mass. 1942): "An attempt to apply a checkerboard set of legal rules would be impractical either in determining the admissibility of cvidence or in charging a jury." 
III

CHolce of Law

The Hartmann case tenders another problem which the court bypassed without comment. In a jurisdiction applying the "single publication rule," what law determines whether an act is a tort? One illustration will suffice. New York holds that the fictionalized version of a person's life for commercial gain, using his true name or picture, constitutes an invasion of his right of privacy. ${ }^{25}$ The same set of facts would not constitute an actionable invasion of privacy in Utah, ${ }^{26}$ Wisconsin, ${ }^{27}$ and perhaps the District of Columbia. ${ }^{28}$ The choice of law, i.e., what law governs, is of the utmost importance. Needless to say, there is no agreement among the courts on this issue. "There are at least ten different and inconsistent theories as to the applicable law, which from time to time have been adopted by some court or suggested by learned writers. No one of them, unless it be the last, can be said to have prevailed and that one only by default." ${ }^{29}$ The various theories are as follows:

I. The law of each place of "impact." This is the multiple-publication theory" and for defamation cases is followed by the Restatement of the Conflicts of Law. ${ }^{31}$ This theory nullifies the "single publication rule."

2. Place of last event. The general Restatement choice of law rule is that the governing law be supplied by the place where the last event takes place which "is necessary to make an actor liable." 32 In defamation and privacy cases, this is the place where publication occurs. ${ }^{33}$ In radio and television, the circumstance that

${ }^{26}$ Binns v. Vitagraph Co., 210 N.Y. 5I, I03 N.E. I108 (1913); cf. Freed v. Loew's, Inc., I75 Misc. 6r6, 24 N.Y.S.2d 679 (Sup. Ct. 1940). See also, Harry P. Warner, Radio and Television Rights $\S 275 b$ (1953), and Garner v. Triangle Publications, Inc., 97 F. Supp. 546 (S.D.N.Y. I95I).

${ }^{30}$ Donahue v. Warner Bros. Pictures, 2 Utah 2d 256, 272 P.2d I77 (r954). Cf. Donahue v. Warner Bros. Pictures, r94 F.8d 6 (roth Cir. 1953), noted in 3 UTAH L. Rev. 247 (1953).

${ }^{27}$ Prest v. Stein, 220 Wis. 354, 265 N.W. 85 (I936); Judevine v. Benzies-Montanye Fuel \& Warehouse Co., 222 Wis. 512, 269 N.W. 295 (1936); Comment, 1952 WIs. L. Rev. 507 (1952).

${ }^{28}$ Bernstein v. National Broadcasting Co., 129 F. Supp. 8r7 (D.D.C. r955), aff'd, 232 F.2d 369 (D.C. Cir.), cert. denied, 352 U.S. 945 (I956).

${ }^{20}$ Prosser, supra note 3, at 971. "There is, however, the further question of what law is to govern each one of the forty-nine causes of action, or any of the component questions of law which may arise in connection with it, and on this, too, there is no agreement. The realm of the conflict of laws is a dismal swamp, filled with quaking quagmires, and inhabited by learned but eccentric professors who theorize about mysterious matters in a strange and incomprehensible jargon. The ordinary court, or lawyer, is quite lost when engulfed and entangled in it." Ibid.

On this problem, see Ehrenzweig, The Place of Acting in Intentional Multi-State Torts: Law and Reason Versus the Restatement, 36 MiNv. L. Rev. I (I95I); Leflar, Choice of Lau: Torts: Current Trends, 6 VAnd. L. Rev. 447 (I953); Note, 63 Harv. L. Rev. 822 (I950).

${ }^{80}$ O'Reilly v. Curtis Publishing Co., 3 I F. Supp. 364 (D. Mass. I940); Holden v. American News Co., 52 F. Supp. 24 (E.D. Wash. 1943), appeal dismissed, 144 F.2d 249 (9th Cir. x944); see Jenner v. Sun Oil Co., [1952] ONt. L. Rep. 240; Kilian v. Stackpole Sons, 98 F. Supp. 500 (M.D. Pa. 195I).

${ }^{31}$ Restatement, Conflict of Laws $\$ 377$ (1934): "The place of wrong is in the state where the last event necessary to make an actor liable for an alleged tort takes place." Rule 5 under this section provides: "Where harm is done to the reputation of a person, the place of wrong is where the defamatory statement is communicated." Illustration 7 likewise provides: " $A$, broadcasting in State $X$, slanders $B . \quad B$ is well and favorably known in State $Y$ and the broadcast is heard by many people conversant with $B$ 's good repute. The place of wrong is $Y . "$

${ }^{32}$ Ibid. See also, Restatement, Torts $\$ 578(\mathrm{~b})$ (1938).

${ }^{33}$ Cf. Banks v. King Features Syndicate, 30 F. Supp. 352 (S.D.N.Y. I939). Sec Notes, 6o Harv. L. Rev. 94I, 946 (I947); 66 Harv. L. Rev. ro4 I, I049 (1949); I6 U. ChI. L. Rev. r64, I67 (I949). 
transmission is both simultaneous and multijurisdictional presents difficulty in determining the "last event."

3. The law of the place of defendant's act. This would be the place at which a broadcast ${ }^{34}$ was made or a magazine or newspaper was published. ${ }^{35}$ This has been criticized in that it would enable a wrongdoer to pick the law that would govern his act, a choice that might result in some state becoming a haven for defaming broadcasters and publishers. This standard is deficient in its application to nationwide telecasts. The infringing act may originate in a remote area hundreds of miles from the New York or Los Angeles studios. ${ }^{36}$ Where, then, does the act occur?

4. The law of defendant's principal place of business. The objection to this theory ${ }^{37}$ is that it is difficult to determine at times the principal place of business of corporate defendants. In addition, the principal place of business may have no real connection with either the act of publication or any injury resulting therefrom.

5. The state of defendant's incorporation or domicile. This approach meets the same objections as the use of defendant's principal place of business. ${ }^{38}$

6. The law of the state of principal circulation. This was suggested by defendant in Bernstein v. National Broadcasting Co. but rejected by the court. ${ }^{30}$ It would mean that the law of New York frequently would govern since that state contains the largest potential circulation or audience.

7. The law of the place of plaintiff's domicile. This standard has frequently been employed by the courts, particularly in defamation ${ }^{40}$ and privacy ${ }^{41}$ cases. This is because the reputation of an individual or his peace of mind is most affected in the locality where he is domiciled. This standard is objectionable where an individual may be domiciled in Connecticut but is employed in New York City. ${ }^{42}$

${ }^{34}$ Mau v. Rio Grande Oil Co., 28 F. Supp. 845 (N.D. Cal. 1939); but ct. Gautier v. Pro Football League, 304 N.Y. 354 , 107 N.E.2d 485 (1952).

${ }^{35}$ Layne v. Kirby, 208 Cal. 694, 284 Pac. 44I (1930); Grant v. Reader's Digest Ass'n, 15I F.2d 733 (2d Cir. 1946).

${ }^{36}$ In Gautier v. Pro Football League, 304 N.Y. 354,107 N.E.2d 485 (1952), the alleged infringing act originated in Washington, D. C., and plaintiff sought recovery in New York.

${ }^{37}$ United States v. Smith, I73 Fed. 227 (D. Ind. 1909); Mishawaka Rubber \& Woolen Mfg. Co. v. Panther-Panco Rubber Co., 153 F.2d 662 (Ist Cir. 1946), cert. denied, 329 U.S. 722 (1946). In Caldwell v. Crowell-Collier Publishing Co., I6I F.2d 333 (5th Cir. 1947), and Addressograph-Multigraph Corp. v. American Expansion Bolt \& Mfg. Co., I24 F.2d 706 (7th Cir. I94I), cert. denied, 316 U.S. 682 ( 1942 ), the court applied the law of the place where plaintiff had its principal business.

${ }^{38}$ Notes, 43 ILl. L. Rev. 556 (1948); 35 VA. L. Rev. 627 (1949). See also, American Radio Stores v. American Radio and Television Stores Corp., 17 Del. Ch. 127, I50 Atl. I80 (Ch. 1930).

${ }^{30} 129$ F. Supp. 817 (D.D.C. I955), affd, 232 F.2d 369 (D.C. Cir.), cert. denied, 352 U.S. 945 , (1956); see Dale System, Inc. v. General Teleradio, Inc., 105 F. Supp. 745 (S.D.N.Y. 1952). Cf.' Palmer v. Mahnin, I20 Fed. 737 (8th Cir. 1903).

${ }^{40}$ Szalatny-Stacho v. Fink, [I947] K.B. I, [1946] I All E.R. 303; Fouts v. Fawcett Publications, Ix6 F. Supp. 535 (D. Conn. 1953); Hazlitt v. Fawcett Publications, Inc., II6 F. Supp. 538 (D. Conn. 1953); Dale System, Inc. v. Time, Inc., II6 F. Supp. 527 (D. Conn. 1953). Cf. Caldwell v. CrowellCollier Publishing Co., I6I F.2d 333 (5th Cir.), cert. denied, 332 U.S. 766 (1947). In the following cases, the courts refused to apply the law of plaintiff's domicile: Christopher v. American News Co., I I F.2d 275 (7th Cir. 1941); Dale System, Inc. v. Gencral Teleradio, Inc., 105 F. Supp. 745 (S.D.N.Y. 1952).

${ }^{11}$ Bernstein v. National Broadcasting Co., 129 F. Supp. 817 (D.D.C. 1955), aff'd, 232 F.2d 369 (D.C. Cir.), cert. denied, 352 U.S. 945 (1956); Ludwig, supra note 3.

${ }_{12}$ Prosser, supra note 3 , at 976: "Apart from the usual difficulty in determining where domicil may 
8. The law of the place where plaintiff has his dominant contacts. A refinement of the domiciliary theory, this standard has been applied in several of the unfair competition cases on the theory that this responds to what constitutes the greatest interference with plaintiff's interests. ${ }^{43}$ The Bernstein case utilized this test since the plaintiff, although domiciled in Virginia, spent the work-week in Washington, D.C., and hence had his dominant contacts in the nation's capital. Judge Learned Hand has likewise applied this standard in a defamation case. ${ }^{44}$ The objection to this theory is that it is-"entirely unpredictable ... [and] impossible to determine in the case of interstate defamatory broadcasts or invasions of privacy, as imposing the law of the more populous states on the rest, and as quite arbitrary where, for example, there are forty jurisdictions involved and the greatest damage in any one is $6 \%$ of the total, against $5 \%$ for the next state. ${ }^{\prime 45}$

Nonetheless, it is believed that the theory of "predominant contacts" is a workable rule. In the defamation cases, there is a twofold injury to the plaintiff-injury to his character or reputation in the eyes of others, and also mental suffering to the individual resulting from the foregoing. ${ }^{46}$ In the privacy cases, the gravamen of the action is injury to the feelings of the plaintiff, the mental distress and anguish caused by the publication. ${ }^{47}$ In both privacy and defamation cases, injury is measured primarily in terms of distress suffered by the plaintiff. The locale of plaintiff's dominant contacts suggests itself as a workable criterion, since here has occurred the greatest interference with plaintiff's peace of mind.

9. The law of the forum. This is the theory most frequently applied by the courts because of convenience, ${ }^{48}$ because the issue was never raised by the litigants, ${ }^{49}$ or

be, this is open to the objection that the publication may have little effect there, or may never reach the place at all, and that where a man of national reputation lives in Nevada the injury in the state may be insignificant in comparison with the whole."

"Socony-Vacuum Oil Co. v. Oil City Refiners, I36 F.2d 470 (6th Cir. I943), cert. denied, 320 U.S. 798 (1943); Triangle Publications v. New England Publishing Co., 46 F. Supp. 198 (D. Mass. 1942).

"Mattox v. News Syndicate Co., 176 F.2d 897 (2d Cir. 1949). To the same effect: Kelly v. Loew's, Inc., 76 F. Supp. 473 (D. Mass. 1948); Neiman-Marcus v. Lait, ro7 F. Supp. 96 (S.D.N.Y. 1952); Banks v. King Feature Syndicate, 30 F. Supp. 352 (S.D.N.Y. 1939); Caldwell v. Crowell-Collier Publishing Co., I6r F.2d 333 (5th Cir. I946), cert. denied, 332 U.S. 766 (1947).

"Prosser, supra note 3 , at 973-74.

${ }^{10}$ Marble v. Chapin, 132 Mass. 225 (1881).

${ }^{17}$ Bernstein v. National Broadcasting Co., 129 F. Supp. 817 (D.D.C. 1955), aff'd, 232 F.2d 369 (D.C. Cir.), cert. denied, 352 U.S. 945 (1956); Reed v. Real Detective Publishing Co., 63 Ariz. 295, 305-6, I62 P.2d I33 (1945). See Annot., I4 A.L.R.2d 750 (1950); HARRY P. WARNER, RAdio and TEleVision RightS II28 (1953).

${ }^{48}$ Spanel v. Pegler, I60 F.2d 619 (7th Cir. I949); Grant v. Reader's Digest Ass'n, 15x F.2d 733 (2d' Cir. 1945); Loyne v. Kirby, 208 Cal. 694, 284 Pac. 44I (1930); Donahue v. Warner Bros. Pictures, 194 F.2d 6 (1oth Cir. 1952); Summit Hotel Co. v. National Broadcasting Co., 336 Pa. 182, 8 A.2d 302 (1939); Holden v. American News Co., 52 F. Supp. 24 (E.D. Wash. I943) appeal dismissed, 144 F.2d 249 (9th Cir. 1944); Leverton v. Curtis Publishing Co., I92 F.2d 974 (3d Cir. 195I); Caldwell v. Crowell-Collier Publishing Co., I6I F.2d 333 (2d Cir. 1946), cert. denied, 332 U.S. 766 (1947).

${ }^{40}$ Melvin v. Reid, Ir2 Cal. App. 285, 297 Pac. 9I (I93I); Gautier v. Pro-Football League, 304 N.Y. 354, 107 N.E.2d 485 (1952); Kelly v. Loew's, Inc., 76 F. Supp. 473 (D. Mass. 1948); cf. Mattox v. News Syndicate Co., I76 F.2d 897 (2d Cir. I949); Mau v. Rio Grande Oil Co., 28 F. Supp. 845 (N.D. Cal. 1939). 
because damages are restricted to one state. ${ }^{50}$ This theory has likewise been criticized. The forum is not always the jurisdiction most significantly connected with the controversy. Since jurisdiction over defendants engaged in nationwide communications may be had in almost every state, plaintiffs may engage in "forum-shopping" with its obvious evils. ${ }^{51}$

Although there is no clear line of cases preferring one theory over the others, there is a trend, as evidenced by the more recent cases, to apply the law of plaintiff's domicile ${ }^{52}$ or, as in Bernstein, the "predominant contacts" theory. ${ }^{53}$ Unfortunatetly, the Uniform Single Publication Act furnishes no aid or comfort in advising a court as to the choice of law. California and other states which have adopted this legislation are free to apply the law of the forum, the "predominant contacts" theory, or the law of plaintiff's domicile. Still, the statute has several advantages over the commonlaw rule, and it is believed that recovery in a state adopting the Act would include damages for the plaintiff's whole wrong. Indeed, one commentator has concluded that the full faith and credit clause of the Constitution absolutely precludes recovery even in states rejecting the "single publication rule" in any later action elsewhere for any part of that whole wrong. ${ }^{54}$

There is an additional facet of the "single publication rule" which warrants discussion. May California in a multiple-publication tort apply its law not only for the injury sustained there, but also for that incurred in the forty-seven other states? The trial convenience in applying the law of one state and instructing the jury on California law only, rather than the laws of New York, Virginia, Maryland, etc., is readily apparent. Judge Learned Hand intimated in Mattox v. News Syndicate Co. the desirability of such an approach, though this was only dictum. ${ }^{55}$

In the Bernstein case, involving a multiple-state privacy action, the court went one step further, applied the "single publication rule," and utilized the law of the District of Columbia in each of the states where plaintiff was seeking damages. In granting defendant's motion for summary judgment, the court had this to say: "If a tortious invasion of privacy be held to have occurred, damages for the injury to plaintiff's feelings would be assessed under the law of the one jurisdiction which is determined to have been his situs, but he could recover there for the whole amount of harm inflicted on his feelings, considering, among other factors, the extent of the publication or publications in that and other jurisdictions." 56 Thus, in Bernstein,

${ }^{50}$ Hartmann v. American News Co., 69 F. Supp. 736 (W.D. Wis. 1947); Levey v. Warner Bros. Pictures, 57 F. Supp. 40 (S.D.N.Y. 1942); Leverton v. Curtis Publishing Co., r92 F.2d 974 (3d Cir. I95I).

${ }^{52}$ Ludwig, supra note 3 , at 760; Prosser, supra note 3, at 977-78.

${ }^{62}$ Dale System, Inc. v. Time, Inc., I16 F. Supp. 527, 530 (D. Conn. 1953); Fouts v. Fawcett Publications, Inc., I16 F. Supp. 535 (D. Conn. 1953); Hazlitt v. Fawcett Publications, Inc., Ir6 F. Supp. 535 (D. Conn. 1953). Cf. Palmisano v. News Syndicate Co., I30 F. Supp. 17 (S.D.N.Y. I955).

${ }^{\text {ta }}$ See notes 43 and 44 , supra.

5' Leflar, The Single Publication Rule, 25 Rocky MT. L. Rev. 263, 276 (1953).

${ }^{60}$ 176 F.2d 897 (2d Cir. 1949). See also Curley v. Curtis Publishing Co., 48 F. Supp. 29 (D. Mass. I942); National Fruit Produce Co. v. Dwinnel-Wright Co., 47 F. Supp. 499 (D. Mass. 1942).

${ }^{80}$ Bernstein v. National Broadcasting Co., rz9 F. Supp. at 826. 
this issue was tendered the court, which applied the law of a single jurisdiction as to each state wherein publication occurred.

\section{IV}

\section{Constitutional Issues}

The Bernstein formula poses several unresolved constitutional issues. May a court apply the substantive law of one state to publications occurring in other jurisdictions? For example, plaintiff brings a multiple-state privacy action in the California courts, seeking damages in such jurisdictions as Nebraska and Wisconsin. These two states have rejected the privacy doctrine. ${ }^{57}$ If the telecast constitutes an actionable invasion of plaintiff's privacy, the court would be confronted with the question of whether plaintiff is entitled to recover damages for publication in $\mathrm{Ne}$ braska and Wisconsin. Since these two jurisdictions refuse on grounds of local public policy to hear this kind of suit, the California court would presumably refuse to grant recovery for publication in these states. California cannot justifiably seek to create greater rights than do the local laws of Nebraska or Wisconsin. ${ }^{58}$

Assume, though, facts similar to Mau v. Rio Grande Oil Co., ${ }^{59}$ wherein plaintiff's action in California for invasion of privacy was sustained, despite defendant's plea that the questioned broadcast was a matter of legitimate public interest. The courts in the District of Columbia ${ }^{60}$ and Georgia ${ }^{61}$ apply an enlarged test of legitimate public interest which is at variance with the holding of the California courts. Thus, had plaintiff brought suit in Washington, D. C., or Georgia, there would have been no recovery. It is hornbook law that the legislative authority of every state is confined to the territorial limits of that state and that California law does not have any effect of its own force beyond the limits of its own sovereignty. ${ }^{62}$ And so a constitutional issue is revealed which has hardly been explored in discussions relating to. the "single publication rule."

The constitutional issue posed by the Bernstein formula is the reverse of the usual torts-conflicts of law problem; there a court must determine whether it will provide a forum for extrastate claims. The contention may be made that to enforce the claim in the forum would be contrary to the local public policy of the jurisdiction, ${ }^{63}$ that it would result in the enforcement of the penal laws of another state, ${ }^{64}$

\footnotetext{
${ }^{87}$ Yoeckel v. Samonig, 272 Wis. 43, 75 N.W.2d 925 (1956); Brunson v. Ranks Army Store, I6r Neb. 519, 73 N.W.2d 803 (1955).

${ }^{88}$ See Herbert F. Goodrich, Handbook of the Conflict of Laws 2I, 223 (3d ed. I949); G. W. Stumberg, Principles of Confict of Laws 988 (2d ed. $195 \mathrm{I}$ ).

${ }^{50} 28$ F. Supp. 845 (N.D. Cal. x939).

${ }^{\circ 0}$ Bernstein v. National Broadcasting Co., I29 F. Supp. 8I7 (D.D.C. 1955), aff'd, 232 F.2d 369 (D.C. Cir.), cert. denied, 352 U.S. 945 (1956).

01 Watcrs v. Fleetwood, 212 Ga. I6I, 9I S.E.2d 344 (1956).

${ }^{02}$ Hilton v. Guyot, 159 U.S. II3 (1895); Alaska Packers Ass'n v. Industrial Accident Comm'n, 294 U.S. 532, 54I (1935): ". . . similar power to control the legal consequences of a tortious act committed. elsewhere has been denied."

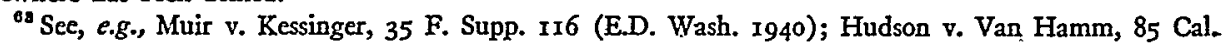
App. 323, 259 Pac. 374 (I927); Kyle v. Kyle, 210 Minn. 204, 297 N.W. 744 (I94I).

os Adams v. Fitchberg Ry., 67 Vt. 76, 30 Atl. 687 (I894). See also 63 A.L.R. r330 (1929).
} 
or that the judicial machinery is unavailable to enforce extrastate law. ${ }^{05}$ The point is raised that under the constitutional requirement of full faith and credit to the "public acts" of every other state, a state may not refuse to entertain a foreign action, such as wrongful death, arising under the acts of another state when there is no clear showing that strong public policy of the forum is violated by the action brought. ${ }^{08}$ Mr. Justice Jackson's language in the United Air Lines case here is pertinent: ${ }^{07}$

For the essence of the Full-Faith and Credit Clause is that certain transactions, wherever in the United States they may be litigated, shall have the same legal consequences as they would have in the place where they occurred.

Undoubtedly, a substantial constitutional argument can be made that a court, in applying the "single publication rule," would be precluded from recognizing a cause of action, such as invasion of privacy, or a defense, such as retraction in a defamation case, with respect to publication in a sister state which refuses to recognize the same action or defense. As long as full faith and credit must be given, it can be persuasively contended that the "single publication rule" cannot be invoked by plaintiff to create a new cause of action or by a defendant to assert a new defense in a foreign jurisdiction which refuses to recognize the same. Despite the constitutional issues tendered by the full faith and credit clause, the Supreme Court could readily conclude that practical considerations require the law of a single state to be applied as to publication in the forty-seven other states. The task before a court in attempting to ascertain and apply the law governing defamation in fortyeight jurisdictions, with its varied defenses, is staggering and defies imagination. ${ }^{08}$ The full faith and credit clause would have to yield to the practical considerations governing the docket of a trial court.

Practical considerations-such as court work-load-have been persuasive factors in shaping and molding constitutional doctrines. One illustration will suffice. Over the years, the Supreme Court has evolved the rules governing the relationships be-

${ }^{65}$ Slater v. Mexican National Ry., 194 U. S. 120 (1904).

${ }^{68}$ Hughes v. Fetter, 34I U.S. 609 (195I). See Notes, 64 Harv. L. REv. 327 (1950), 51 Mrar. L. REv. 267 (1952).

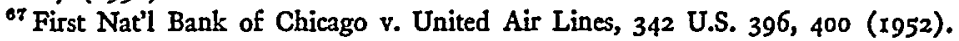

${ }^{88}$ See note 24 , supra. See Wyzanski, J., in National Fruit Produce Co. v. Dwinnel-Wright Co, 47 F. Supp. 499, 504 (D. Mass. 1942): 'I prefer to believe that the Massachusetts court has the robust common sense to avoid writing opinions and entering decrees adapted with academic nicety to the vagaries of forty-eight states. And until Massachusetts adopts a checker-board jurisprudence, the Klaxon case does not require this court to do so."

See Goodrich, J., in Leverton v. Curtis Publishing Co., 192 F.2d 974, 975 (3d Cir. 1951): "This is the kind of case where, if all of the questions which could be pointed up by analysis were to be answered, we should find ourselves in a forest from which it would be pretty hard to escape. Where was the right of privacy invaded, for instance: Alabama where the plaintiff lived, Pennsylvania where the Saturday Evening Post was published, or every state in the Union to which the Post goes? If so, is there a separate lawsuit for each invasion? Does recovery in one action for one invasion preclude suit in some other state for another invasion? Because Pennsylvania bas the 'single-publication' rule in defamation, is the same thing true for invasion of privacy? Questions similar to this the court was compelled to face in Hartmann y. Time, Inc. (3d Cir. 1948), 166 F.2d 127, I A.L.R.2d 370. Fortunately, for judicial peace of mind, we do not have to face them here." 
tween courts and administrative agencies. ${ }^{69}$ A federal appellate court today cannot review de novo the factual determinations of an administrative agency. The socalled jurisdictional or constitutional fact doctrine, which permitted a court to review de novo the findings of an administrative agency, yielded to the work-load confronting appellate courts. ${ }^{70}$ The size of the records and the volume of cases on appeal was an important factor in prompting the Supreme Court to adopt the self-imposed limitation on reviewing courts-that the findings of fact, if supported by substantial evidence, are conclusive. ${ }^{71}$ With practical factors in mind, it is believed that the courts will consider the full faith and credit clause to be consistent with the adoption and extension of the Bernstein formula to the "single publication rule."

\section{$\mathrm{V}$}

\section{Defamation}

There have been several cases which have discussed the application of the "single publication rule" to defamatory utterances over radio and television. The areas of controversy surrounding broadcast or telecast defamation highlight the need for the "single publication rule" to limit issues to workable bounds where a program has been received in several states.

Many radio and television defamation cases have been concerned with such issues as whether the tort is libel ${ }^{72}$ or slander. ${ }^{73}$ Thus, if a broadcaster reads from a script, it is considered libel; on the other hand, an ad-lib interpolation is considered slander. ${ }^{74}$ Other courts have suggested that defamation by radio be treated as a "new tort," containing the characteristics of both libel and slander and subject to a standard of due care. ${ }^{75}$ The cases are likewise in conflict on the issue whether defamation by television constitutes libel or slander. ${ }^{76}$ The courts agree that motion pictures would

${ }^{\circ 0}$ Kenneth C. Davis, Cases on Administrative Law 868 et seq. (I951); Universal Camera Corp. v. NLRB, 340 U.S. 474 (I95I); Jaffe, Judicial Review: Substantial Evidence of the Whole Record, 64 Harv. L. Rev. 1233 (195r); F. E. Cooper, Administrattve Agencies and the Courts c. 18, at 330 et seq. ( $195 \mathrm{I})$.

${ }^{70}$ Crowell v. Benson, 285 U.S. 22 (r932); St. Joseph Stockyards v. United States, 298 U.S. ${ }_{3}^{8}$ (r936). See Jaffe, Judicial Review: Constitutional and Jurisdictional Fact, 7o HARv. L. REv. 953 (1957).

${ }^{71}$ Section 1o(c) of the Administrative Procedure Act, 60 STAT. 243 (1946), 5 U.S.C. $\$$ roog(e) (1952), embodies this legislation.

${ }^{73}$ Sorenson v. Wood, 123 Neb. 348, 243 N.W. 82 (r932); Coffey v. Midland Broadcasting Co., 8 F. Supp. 889 (N.D. Mo. 1934).

${ }^{73}$ Meldrum v. Australian Broadcasting Co., [1932] Vict. L. Rev. 425. See Harry P. Warner, Radio and TeleVision LAW $\$ 37$, at 444 (1953).

7' See Warner, loc. cit. supra note 73. See also Hartman v. Winchell, 296 N.Y. 296, 73 N.E.2d 30 (1947); Locke v. Gibbons, I64 Misc. 877, 299 N.Y. Supp. 188 (Sup. Ct. 1937), affd, 253 App. Div. 887, 2 N.Y.S.2d 1015 (Ist Dep't 1938); Weglein v. Golder, 317 Pa. 437, 177 Atl. 47 (r935).

${ }^{75}$ Summit Hotel Co. v. National Broadcasting Co., 337 Pa. 182, 8 A.2d 302 (1939); Kelly v. Hoffman, 137 N.J.I. 695, 6r A.2d 143 (Ct. Err. \& App. I948); Irwin v. Ashurst, 158 Ore. 6r, 74 P.2d Ir27 (1938).

${ }_{70}$ Remington v. Bentley, 88 F. Supp. 166 (S.D.N.Y. 1949) held that defamation by television was slander. Contra, Shor v. Billingsley et al., I4 R.R. 2053 (N.Y. Sup. Ct. x956); Landau v. Columbia Broadcasting System, to R.R. 2017 (N.Y. Sup. Ct. 1954). 
be considered libel; ${ }^{77}$ in the case of theatrical film, exhibited over television broadcast stations, the same rule would undoubtedly apply.

In addition to such disputed issues, viz., whether the tort is libel, slander, or both, there is a raging controversy as to whether broadcasters should be held accountable to the same standard of strict liability as newspapers. ${ }^{78}$ The cases are evenly divided, with four holding the station to be strictly liable, ${ }^{79}$ and four applying the standard of due care. ${ }^{80}$ In this connection, a large number of states have enacted legislation which mitigates a broadcaster's liability for defamatory statements made by persons who are not agents of the broadcaster if the latter has exercised due care to prevent the utterance of such statements. ${ }^{81}$ Two states have gone so far as to relieve the broadcaster of liability for defamation by persons who are not agents, regardless of any negligence on the part of the broadcaster. ${ }^{82}$

Defamation by radio and television is further complicated by section 315 of the Communications Act of $1934^{83}$ That provision requires a station to afford equal opportunities to all legally qualified candidates for public office and precludes a station from exercising any power of censorship over the material broadcast. ${ }^{84}$ The legislative history and background of this provision indicated that, in the absence of federal control in this area, the common law and state statutes on libel and slander were deemed sufficient to protect the civil rights of any individual who had been defamed. ${ }^{85}$

From the inception of federal control of broadcasting in 1927 to 1948 , broadcasters had examined political scripts and had deleted material which, in their opinion, was defamatory ${ }^{86}$ But in the Port Huron decision, published in 1948, the Federal Communications Commission advised the industry that "the prohibition of section 315 against any censorship by licensees of political speeches by candidates for office

${ }^{77}$ Youssoupoff v. Metro-Goldwyn-Mayer Pictures, 50 T.L.R. 58x, 99 A.L.R. 864 (1934); Kelly v. Loew's, Inc., 76 F. Supp. 473 (D. Mass. 1948).

${ }^{78}$ See WARNER, loc. cit. stipra note 73.

${ }^{78}$ Sorenson v. Wood, 123 Neb. 348, 243 N.W. 82 (1932); Miles v. Louis Wasmer, 172 Wash، 466, 20 P.2d 847 (1933); Coffey v. Midland Broadcasting Co., 8 F. Supp. 889 (N.D. Mo. 1934); Irwin v. Ashurst, 158 Ore. 6r, 74 P.2d I127 (1938).

${ }^{80}$ Summit Hotel Co. v. National Broadcasting Co., 337 Pa. 182, 8 A.2d 302 (1939); Josephson v. Knickerbocker Broadcasting Co., 179 Mis. 787,38 N.Y.S.2d 985 (Sup. Ct. 1942); Kelly v. Hoffman, I37 N.J.L. 695, 6I A.2d 143 (Ct. Err. \& App. 1948); Parker v. Silver City Crystal Co., 12 R.R. 2057 (D. Conn. 1955).

${ }^{81}$ See, e.g., Cal. Civ. Code $\$ 48.5$ (I949); Mrch. Stat. ANn. $\$ \$$ 27-1405-06 (Supp. I953). Sce Remmers, supra note 3; Leflar, Radio and TV Defamation: "Fanlt" or Strict Liability, is Omo ST. L. J. 252 (1954).

${ }_{82}$ Miss. Laws, c. 250, at 274 (1954); N. D. Rev. CODE $\$ 14-0209$ (Supp. 1953).

${ }^{83} 48$ STAT. I088 (1934), 47 U.S.C. \$315 (1952).

ss " $315(a)$. If any licensee shall permit any person who is a legally qualified candidate for any public office to use a broadcasting station, he shall afford equal opportunities to all other such candidates for that office in the use of such broadcasting station: Provided, That such licensee shall have no power of censorship over the material broadcast under the provisions of this section. No obligation is imposed upon any licensee to allow the use of its station by any such candidate."

${ }^{86}$ Harry P. Warner, Radio and Television Law $\$ 32$ (1949).

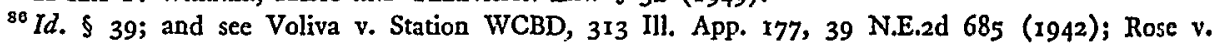
Brown, I86 Misc. 553, 58 N.Y.S.2d 654 (1945). 
is absolute and no exception exists in the case of material which is either libelous or might tend to involve the station in an action for damages."

The Commission was then faced with this problem: Several of the state courts had held broadcasters responsible for defamatory remarks uttered over a station in a political broadcast. ${ }^{88}$ These decisions, in effect, affirmed the right of broadcast licensees to examine political scripts and to delete such material which was defamatory in character. The Commission answered this contention by concluding that Congress had pre-empted this field of censorship and thus relieved licensees of both power to delete and responsibility for any defamatory matter broadcast in a political speech. The Commission's conclusion as to liability of the broadcaster would not, of course, bind the courts.

Although this situation has been discussed at great length in Congress, no federal remedial legislation has been enacted to resolve the dilemma of the broadcaster. In the absence of congressional relief, broadcasters have appealed to their state legislatures for help. The latter have enacted legislation giving the broadcaster complete immunity from political defamatory utterances. ${ }^{89}$

The Commission's decision in the Port Huron case portends a possible solution for the vexatious problems in this troublesome field. Clearly radio and television are interstate communications premised on the commerce clause of the Constitution; $;^{90}$ and Congress, in enacting the Communications Act of 1934, has pre-empted this field to the exclusion of the states. This pre-emption could be extended to torts in interstate publication. ${ }^{91}$ Such legislation, if adopted by Congress, could adopt the Bernstein formula of the "single publication rule." It could go further and spell out whether defamation by radio is libel or slander, whether a broadcaster should be held accountable to the rule of strict liability. The area of privilege also could be delineated, and the statute might declare the effect of a retraction or of the plaintiff's failure to demand the same.

Let us retreat from the field of possible legislation to the published decisions dealing with the application of the "single publication rule" to defamatory utterances over radio and television. Dale System $v$. Time, Inc., ${ }^{92}$ involved a multistate libel effectuated by the publication of Life and a broadcast over radio station WOR.

${ }^{87} \mathrm{Re}$ Port Huron Broadcasting Co. 12 F.C.C. 1069 (1948). See also Houston Post Co. v. United States, 79 F. Supp. 199, 203 (S.D. Texas 1948); Harry P. Warner, Radio and Television Law $\$ 34$ e (1949).

${ }^{88}$ See cases cited note 79 supra.

${ }^{80}$ See, e.g., Mo. Ann. Stat. $\$ 537.105$ (1953); N.Y. Sess. Laws 1955, c. 580, $\$$ I. See also Felix v. Westinghouse Radio Stations, I86 F.2d I (3d Cir. I950), cert. denied, $34 \mathrm{I}$ U.S. 909 (I95I); Note, 30 ST. Jorn's L. REv. I26, I37 (1956). But see the recent case of Farmers' Cooperative Union v. Townley, I5 R.R. 2058 (D. N.D. I957), wherein it was held that a state statute absolving a broadcast station from any liability for libel, slander, or negligence is unconstitutional. This case is on appeal.

${ }^{D 0}$ Federal Radio Comm'n v. Nelson Bros. Bond \& Mtg. Co., 289 U.S. 266 (1933).

${ }^{01}$ See Second Employers' Liability Act Cases, 223 U.S. I (1912); O'Brien v. Western Union Telegraph Co., 113 F.2d 539 (Ist Cir. 1940); Vaigneur v. Western Union Tel. Co., 34 F. Supp. 92 (E.D. Tenn. 1940); Haviland v. Western Union Tel. Co., I19 F Supp. 438 (S.D. Texas r954). Note, 67 Harv. L. REv. 347 (1953).

${ }_{11} 6$ F. Supp. 527 (D. Conn. 1953). 
Plaintiff alleged that an article published in Life and summarized in the Reader's Digest was libelous in that it injured plaintiff's business. The summary in the Reader's Digest was broadcast over Station WOR. "The broadcast took place from a studio in New York City, but was accomplished through a transmitter located in New Jersey. The broadcast could be heard from Massachusetts to Georgia." ${ }^{\text {"03 }}$

The court held that the publications in Life and Reader's Digest and the broadcast constituted "three torts." Despite the publication of the libel in more than three states, the court applied the "single publication rule" and also decided that the law of plaintiff's domicile was the law to be applied to a multistate libel which had been communicated in the state of plaintiff's domicile as well as in other jurisdictions. The significance of this decision is that a lower court not only applied the "single publication rule" but went one step further, utilized the Bernstein formula, and applied the substantive law of the domicile to govern publications in other jurisdictions, i.e., from Massachusetts to Georgia.

Hawser v. Pearson, ${ }^{94}$ with an almost identical factual pattern, is squarely in conflict. There, plaintiff brought a libel action, claiming that a broadcast originating in the District of Columbia and heard in California and nine other western states was defamatory. Judge Holtzoff, rejecting the "single publication rule," held that "libel and slander take place where the defamatory statement is communicated and not in the place from which the offending material is sent or where it originates. ... [T] he substantive law of each of the States in which the defamatory matter was circulated should govern the rights and liabilities of the parties in respect to so much of the circulation of the offending material as took place in that State."0s Thus, Bernstein and Hawser v. Pearson, from the same jurisdiction, are in conflict on the application of the "single publication rule."

The last case to be discussed under this topic is Dale System, Inc. v. General Teleradio, Inc. ${ }^{98}$ a multistate libel action, with the broadcast originating in New York City and heard by listeners from Maine to North Carolina and as far west as Harrisburg, Pennsylvania, and elsewhere. The court applied the "single publication rule" but approached the problem by treating it as a choice of law issue. Judge Murphy held first that a multistate libel action does not present a choice of law problem unless it is significantly related to more than one jurisdiction and, secondly, its determination on the merits varies according to which related jurisdiction supplies the governing internal substantive law.

It was conceded that the tort controversy was multistate in character, but "whether internal law of related jurisdictions is significantly different, must remain conjectural unless thorough canvass is made of the internal rules of all states within broadcast range. We think that part of the office of conflict-of-laws is to obviate such investigation by making available rules for choice of governing law in controversies with important contacts overflowing the boundaries of a single state."

\footnotetext{
${ }^{\circ 3} \mathrm{Id}$. at 529 .

${ }^{25} \mathrm{Id}$. at 938,939 .

${ }^{84} 95$ F. Supp. 936 (D.D.C. 195I).

${ }^{\circ 7}$ Id. at 747-48.

${ }^{28}{ }_{105}$ F. Supp. 745 (S.D.N.Y. 1952).
} 
Judge Murphy then applied the substantive law of New York to determine whether the complaint stated a cause of action. New York law governed because it was the law of the forum, the point of origination of the broadcast, and the state of principal circulation. The significance of this opinion in relationship to the "single publication rule" is the apparent adoption of the Bernstein formula not only for libel and slander, but also for other multistate torts-intentional infliction of harm, negligent use of words, and "penumbral competitive torts," like trade disparagement, trade libel, slander of goods, and injurious falsehood.

\section{VI}

\section{UNFAIR COMPETITION}

The extent to which the "single publication rule" has been invoked in the unfair competition $^{98}$ cases is aptly illustrated by Ettore v. Philco Television Broadcasting Corporation, ${ }^{99}$ which involved the telecasting of motion picture film of the 1939 Ettore-Joe Louis fight. An edited version of the fight was telecast on two different occasions in 1949 and 1950 over the nationwide facilities of the National Broadcasting Company. Plaintiff sought damages in four states-Pennsylvania, New York, New Jersey, and Delaware-claiming that he had never sold his television rights or consented to the telecasts.

Plaintiff in his complaint invoked the privacy doctrine, the law of unfair competition, and a "kind of property right to the product of his services" for the unauthorized exhibition of fight films. A preliminary issue before the court was whether Ettore, who sold his motion picture rights in 1939, waived his property rights therein and thus agreed in advance to any use, commercial or otherwise, to which the films could be put. The court had some difficulty with this point, particularly as Ettore did not expressly reserve rights against the televising of the films. Judge Biggs concluded, however, that Ettore had impliedly reserved his television rights, on the theory that at the time Ettore sold his motion picture rights, television was an unknown medium, and, hence, fairness would seem to require the court to treat the absence of this new or unknown medium as the equivalent of a reservation against the use of his work product or performance. ${ }^{100}$

In holding that Ettore had a property right in his performance as a fighter and hence could enjoin the telecasts, Judge Biggs commingled and confused all three theories-privacy, unfair competition, and property right to the product of his services. It would appear Ettore would be hard-pressed to rely on the privacy doctrine, which is primarily concerned with the protection of an individual's mental interests against offense to his sensibilities caused by unwanted and unwarranted publication of his likeness or activity. ${ }^{101}$ As the dissenting opinion points out, "As a

${ }^{08}$ For a discussion of the extent to which the law of unfair competition is applicable to the content of radio and television programs, see Harry P. Warner, Radio and Televiston Rights 889 et seq. (I953).

${ }^{D 0} 229$ F.2d 48I (3d Cir. 1956), cert. denied, 35I U.S. 926 (1956).

${ }^{100}$ See Harry P. Warner, Radio and Television Rights 889 et seq. (1953), and cases cited therein.

${ }^{102}$ Id. at 988. And see RCA Mfg. Co. v. Whiteman, II4 F.2d 86 (2d Gir. 1940), cert. denied, 
participant in a professional prize fight, Ettore was seeking as large an audience for his performance as promotional skill could attract to ringside and theatres where the fight films were subsequently exhibited. The addition of a television audience cannot rationally be regarded as making the publication offensive to the performer." 102

The legal theory underlying Ettore's right of recovery is that he has some sort of a property right in the product of his services; this is protected by the law of unfair competition, which grants relief for the misappropriation to the commercial advantage of one person of a benefit or property right belonging to another.

To return to the interstate publication issues, Ettore claimed he was damaged in four states-New York, New Jersey, Pennsylvania, and Delaware. The program was telecast by NBC over its own New York station and by its Philco affiliate, WPTZ in Philadelphia; ${ }^{103}$ there were two telecasts of the Ettore-Louis fight-on December 30 , 1949, and again on December 8, 1950. As discussed elsewhere, Pennsylvania does not employ the Bernstein formula in its application of the "single publication rule." The court is required to examine the law of each jurisdiction where the plaintiff claims injury. Judge Biggs concluded, despite the paucity of case law, that New York, Delaware, and New Jersey, in addition to Pennsylvania, would recognize a cause of action in Ettore's behalf. Since there were two telecasts, separated a year apart, Ettore had two causes of action.

The next question was whether the suit instituted in Pennsylvania would bar litigation on the same causes of action in New Jersey and Delaware. Pennsylvania is governed by the "single publication rule," as previously noted, but the law in that jurisdiction requires the court to determine whether New Jersey and Delaware would likewise apply the "single publication rule." Judge Biggs examined the laws of both states and concluded that, despite no technical trace of any New Jersey or Delaware law pertinent to the issue, public policy and logic warranted the conclusion that they would follow the Pennsylvania "single publication rule." Hence, the "single publication rule" resulted in two separate causes of action (because of two telecasts of the same program a year apart); and it engrossed the telecasts in New Jersey and Delaware.

The NBC station in New York likewise telecast these programs. On the basis of the stipulated facts before the court, it was alleged that Ettore's rights were violated four times in New Jersey-twice by the Philadelphia station and twice by the New York station. In this connection, it should be pointed out that NBC was not named as a party to the suit; Chesebrough Manufacturing Company, the sponsor, was served as a party defendant.

Judge Biggs held that since the New York and Pennsylvania telecasts took place

311 U.S. 712 (1940); Peterson v. KMTR Radio Corp., Civil No. 557, 555, Cal. Super. July 7, 1949, 18 U.S.L. WEER 2044 (July 26, 1949).

${ }^{102} 229$ F.2d at 496.

${ }^{203}$ NBC now owns WPTZ. Its call letters are WRCV-TV. 
at the same time and since New York follows the "single publication rule," the causes of action in New York and New Jersey against Chesebrough would be engrossed by the Pennsylvania suit. In other words, the causes of action against Chesebrough in New York and Pennsylvania was merged, and plaintiff could recover damages as a result of the New York telecast.

The court then referred to the fact that there were four telecasts in New Jersey. It suggested that the telecasts from the New York station were seen in northern New Jersey and from WPTZ, in southern New Jersey. "If Ettore is able to prove that the telecasts were seen and heard in New York and by persons in the northern part of New Jersey who did not view the Philco Pennsylvania telecasts, by reason of the physical limitations imposed on television, he might be able to assert additional elements of damage." 104

The Ettore case demonstrates the "ferocious task" confronting a court in applying the Hartmann rule. ${ }^{105}$ Not only was the court required to examine into the conflicts of law rule of four states and ascertain the existence and application of the "single publication rule," but the court had to determine the substantive law of all four states as to the existence of causes of action. The court was in a forest of but four states deep; it would have been an impenetrable jungle were there fifteen states involved.

\section{VII}

\section{The Right of Privacy}

The facts in Bernstein v. National Broadcasting Co. warrant detailed analysis because the various issues relating to the "single publication rule" were discussed by Judge Keech in the lower court opinion. Bernstein sought compensatory and punitive damages for invasion of his privacy by reason of a nationwide telecast in twentynine jurisdictions, including the District of Columbia. Bernstein filed two suits: the first was drafted on the single tort theory, viz., that the telecast over Station WNBW, Washington, D. C., infringed his privacy; the second was drafted on the multiple tort theory, i.e., that plaintiff was entitled to compensatory and punitive damages for the publication of the tort in twenty-eight different states excluding the District of Columbia. The telecast which was the basis of the instant litigation was the "Big Story" program, consisting of film and live action and emanating from New York City. The program was transmitted "live" to a minimum of thirty-eight stations; ten stations telecast the program on a delayed basis via kineoscope recordings. Plaintiff in the Bernstein case was domiciled in Virginia; he was employed by the War Department in Washington, D. C., and occupied a room in that city during the work week.

The first issue confronting the court was the governing choice of law. Judge

104229 F.2d at 495 .

${ }_{105}$ Judge Biggs opened the Ettore opinion with the following: "On this appeal we find ourselves within that forest ruefully referred to by Judge Goodrich in Leverton v. Curtis Pub. Co., 3 Cir. I95x, 192 F.2d 974, 975. The forest in this case, however, is only four states deep." "229 F.2d at 483. 
Keech analyzed the privacy doctrine and concluded that the applicable governing law should be the jurisdiction where plaintiff sustained injury. "The injury in these cases is the humiliation and outrage to plaintiff's feelings, resulting from the telecast." ${ }^{\text {"106 }}$ Since the impact of the multistate tort occurred in one place, the court agreed to apply the law of that jurisdiction where plaintiff was when his feelings were wounded.

The next issue before the court was whether it should apply the law of the state of Virginia, where plaintiff was domiciled, or of Washington, D. C., where the plaintiff had his dominant contacts. The objection to applying the law of Virginia was the existence of a partly penal statute, ${ }^{107}$ patterned after the New York law ${ }^{108}$ and which undoubtedly would be strictly construed. The District of Columbia, on the other hand, with but one or two cases dealing with the privacy doctrine, would be governed by the common law ${ }^{109}$-much more flexible than its statutory counterpart. In the Bernstein case, it was held that plaintiff had no cause of action, since the disclosure of his past life involved matters of legitimate current public interest. Judge Keech concluded that the foregoing result applied whether the common law or its statutory counterpart governed. But on the issue, the court concluded as a matter of law that the governing choice of law would be that of the jurisdiction where plaintiff had his dominant contacts, in lieu of domicile.

The basic issue before the court was whether it should apply the "single publication rule." To quote Judge Keech: "If a tortious invasion of privacy be held to have occurred, damages for the injury to plaintiff's feelings would be assessed under the law of the one jurisdiction which is determined to have been his situs, but he could recover there for the whole amount of harm inflicted on his feelings, considering, among other factors, the extent of the publication or publications in that and other jurisdictions." S10 Significantly, in this Bernstein opinion, the court not only applied the "single publication rule," but it applied the substantive law of the District of Columbia for the twenty-eight jurisdictions where publication occurred.

The court's opinion left open the so-called "academic question,"-whether the "single publication rule" encompassed telecasts on subsequent dates or at subsequent times. No court has had occasion to discuss this problem in relation to radio or television broadcasting. In the early days of television, kineoscope recordings were in frequent use because of the absence of relay or microwave facilities between and among stations. Today, most of the major markets across the country are interconnected through the facilities of the American Telephone \& Telegraph Company. However, because of the different time zones, programs on the West Coast are taped

${ }^{100} \mathrm{Id}$. at 825 .

${ }^{207}$ VA. Code ANN. $\$ 5782$ (I942).

${ }^{108}$ N.Y. Crvil Righrs Law $\$ 50$ and 51. See Levey v. Warner Bros. Pictures, 57 F. Supp. 40, 42 (S.D.N.Y. I944); Binns v. Vitagraph Co., 210 N.Y. 51, 103 N.W. 1108 (1913); Freed v. Loew's, Inc., 175 Misc. 6r6, 24 N.Y.S.2d 679 (Sup. Ct. 1940).

${ }_{100}$ Peed v. Washington Times Co., 55 Wash. L. Rep. (I927); Peay v. Curtis Publishing Co., 78 F. Supp. 305 (D.D.C. 1948); Elmhurst v. Pearson, 153 F.2d 467 (D.C. Cir. 1946), affirming 58 F. Supp. 484 (D.D.C. 1945).

${ }_{110} 129$ F. Supp. at 826 . 
or kineoscoped for broadcasts at specified times. The advent of electronic tape suggests that an increasing number of programs will be taped and distributed at more convenient hours for a station's listening or viewing audience.

A sponsor who utilizes the facilities of a national network is presumably seeking nationwide advertising for his product or services. The single distribution of the program on the same day, but at different times during the day, to accommodate the differences in time zones, would indicate that we are dealing with but one nationwide publication, and hence a single tort. Similarly, if several stations are precluded from carrying a specific program on the day that a majority of the stations broadcast it, because of contractual commitments, but televise the specific program within a reasonable period thereafter, it should likewise be treated as part of the nationwide publication.

The foregoing tenders another problem. The initial telecast of a nationwide program in thirty-four states occurs on March 20, 1957; the same telecast for five stations occurs one month later. The statute of limitations issue is readily apparent, particularly if the telecasts for the five stations enlarge the time for bringing suit.

There is no ready answer for the myriad problems which will confront a court in its attempted application of the "single publication" or multiple-publication rules. Courts and litigants will require further experience before workable rules and policies emerge.

\section{VIII}

\section{ConcLusion}

The need for the "single publication rule" is readily apparent. The interstate tort with its multistate publications calls for such a doctrine. The logical development of this doctrine suggests that the "single publication rule" be extended to authorize a court's applying the law of one state for the publication in the other forty-seven states. Practical considerations dictate such a development. If a court adheres to the philosophy enunciated in the Ettore case, it will be in an impenetrable jungle from which there is no escape. Limitations of time alone preclude a court from examining the substantive and choice of law issues in a multistate defamation action in forty-eight states. Furthermore, how can any court instruct a jury on the varying laws, defenses, privileges, and damages of fory-eight states?

Despite the practical needs and demands for the "single publication rule," there is an undefined constitutional law area which looms as an obstacle to the logical extension of the "single publication" philosophy. To restate the issue, may a court, in applying the "single publication rule," create a cause of action in those jurisdictions which refuse to recognize a tort, e.g., invasion of privacy? Such jurisdiction may have varying defenses or privileges which for all practical purposes nullify the tort. The full faith and credit clause is not a sacrosanct and unyielding philosophy: Thus, it is conceivable that this doctrine may be modified by the Supreme Court to enable lower courts to deal with an intensely. practical problem which can only be handled by the philosophy enunciated by the "single publication rule." 